\title{
Sarayda Olmak Esaret mi, Saadet mi? Gecenin Yalnzzh̆ğı Adlı Romanda Abdülkadir Merâgi'nin Yönetenlerle İlişkileri ve Müzik Çalışmaları
}

Necmettin ÖZMEN

\begin{abstract}
$\ddot{O} \mathbf{z}$
Selma Fındıklı tarafından kaleme alınan Gecenin Yalnzzhğında adlı romanda ünlü Türk musiki nazariyatçısı, bestekâr ve icracı Kemâleddin Abdülkadir b. Gaybî el-Merâgi'nin hayatı anlatılır. Roman, Sahand Dağını Ötesi, Yaz 1373/Meraga; Gönüller Bülbülü, Kış 1375 / Tebriz; Elf Leyle vü Leyle, Sonyaz 1386 / Bağdat; Efrasyab Ülkesi, İlkyaz 1397/Semerkand; Gecenin Yalnzzhğında, İlkyaz/1435 Herat başlıklı bölümlerden oluşur. Abdülkadir Merâgi, Meraga'da kendi hâlinde yaşarken Tebriz'deki Celayirli sarayına davet edilir. Bu davet onu: "Ne buyrulursa onu çalmak, ne arzu edilirse onu söylemek zorundayım bundan sonra” düşüncesine sevk eder. Sarayda sürekli endişelidir. Sultan Üveys ve oğlu Şehzade Hüseyin'le beraberdir ama: "Gök kubbede parıldayan yıldız gibi genç yaşta herkesi kıskandıracak saygınlı̆̆a erişmiş olsam da ayaklarım buyrukla yön buluyor. Kula kulluk değil de nedir bu?” diye kendi kendini sorgular. Bir yandan da müzik çalışmalarına devam eder. Şehzade Hüseyin sultan olduktan sonra dönemin büyük musiki bilgini Rıdvanşah ile nevbet-i mürettep besteleme hususunda önemli bir bahse girer. Sarayda üst düzey insanlara musahip olmasına, etrafinca sevilmesi ve sayılmasına, yöneticilerin meclislerinde fikir söyleyebilmesine rağmen Merâgi genelde mutlu olamaz. Sarayda bir eli yağda bir eli balda olduğu düşünülen sanatkârların aslında öyle olmadığını gösteren bir örnek olması bakımından da Gecenin Yalnzzhğında Türk roman tarihi açısından önemlidir. Bundan dolayı çalışmamızda bu roman bağlamında, hayatının büyük kısmı saraylarda-savaşlarda geçen Abdülkadir Merâgi'nin yaşananlar karşısındaki psikolojik durumu, yönetenler (sultanlar) hakkındaki düşünceleri, çektiği sıkıntılar ve müzik çalışmalarını nasıl yaptığı incelenmiştir.
\end{abstract}

Anahtar kelimeler: Merâgi, nevbet-i mürettep, müzik-iktidar ilişkisi.

\section{Living in a Palace Slavery or Happiness? The Novel Named Gecenin Yalnzzlı̆̆nda Abdülkadir Merâgi's Relationship with The Government Relations and Musical Work}

\begin{abstract}
Famous Turkish musical composer performer Kemâleddin Abdülkadir b. Gaybî el-Merâgs life is told in the novel named 'Gecenin Yalnuzhğında' written by Selma Fındıklı. Novel; 'Sahand Dağının Ötesi, Yaz 1373 / Meraga; Gönüller Bülbülü, Kış 1375 / Tebriz; Elf Leyle vü Leyle, Sonyaz 1386 / Bağdat; Efrasyab Ülkesi, İlkyaz 1397 / Semerkand; Gecenin Yalmzzhğında, İlkyaz / 1435 Herat' as titles of the chapters. Merâgi is invited to Tabriz, Celayirli palace. This invitation makes him think that 'I have to play and sing whatever is demanded from now on'. There are some concerns that arise in his mind when Sultan Üveys and his son Şehzade Hüseyin come together. He questions himself 'Even though I have reached the potential to make everyone jealous in a young age like a sparkling star in the open sky, I can find my path with orders 'If this isn't being a servant (kul) to another servant then what is it?'. Sultan Hüseyin along with the great known musician Rıdvanşah narrates on a composition
\end{abstract}

Dr. Öğr. Üyesi, İstanbul Sabahattin Zaim Üniversitesi, Eğitim Fakültesi, Türkçe ve Sosyal Bilimler Eğitimi Bölümü, necmettin.ozmen@izu.edu.tr [Makale kaylt tarihi: 2.3.2018-kabul tarihi: 14.4.2018] 
Living in a Palace Slavery or Happiness? The Novel Named Gecenin Yalnızh̆̆ında Abdülkadir Merâgi’s Relationship with The Government Relations and Musical Work / N. Özmen (p. 59-73)

named 'nevbet-i mürettep'. Meragi does not feel happy although he is surrounded by high-ranking people who love, respect and give him the privilege to express his opinions in the councils of the rulers. In this respect, Gecenin Yalnzzhğı is an important work for Turkish novel as it reflects the realities of artists who seem to enjoying the glamarous life in palace. False representations of the artists will be even more obvious in the current study. This study aims to analyze Abdülkadir Meragi's actions and reactions in the face of wars at that time and difficulties he experienced. Moreover, the process of creation of his work in the midst of these turmoils will be one of the focuses this study.

Key words; Merâgi, nevbet-i mürettep, music-government relations.

\section{Giriş}

Abdülkadir Merâgi Türk musiki tarihinin en önemli isimlerinden biridir. Merâgi’nin önemini Kolukırık (2012) şöyle anlatır:

“Safiyüddin'den sonra bu alanda eserleriyle ve çalışmalarıyla Hoca Abdülkadir Merâgi'nin önemli bir yeri vardır. Türk musikisinin her konudaki zirve ismi olan Abdülkâdir Merâgi’nin musiki düşüncesi ve eserlerinin değerlendirilmesi konusunda yeterince çalışma yapılmadığını söyleyebiliriz.”

Uslu (2017) ise şunları söyler:

“Abdülkadir Merâgi, Türk müziğinin önde gelen teorisyenlerinden biridir. Sistemci okulun en önemli temsilcisi ve yorumcusudur. Hayatı hakkında bilinmeyenlerin ortaya çıkarılması müzik tarihinin problemlerinden biridir. Kendi yazdıklarından hayatıyla ilgili bilgilerin ortaya çıkarılmasında bile zaman zaman ihmaller görülmüştür."

Abdülkadir Merâgi'nin ölümü üzerinden yüzyıllar geçtiği hâlde hakkında yapılan çalışmaların yetersizliği karşısında Kubilay Kolukırık ve Recep Uslu’nun ne kadar haklı olduğu kolaylıkla meydana çıkar. ${ }^{2}$ Bu yazının konusu esasında Selma Fındıklı (2002) tarafından kaleme alınan ve Merâgi'nin hayatının anlatıldığı Gecenin Yalnızlı̆̆ında adlı roman bağlamında, Merâgi'nin, neredeyse sürekli savaş durumunda olan iktidar sahipleri ile (sultanlarla) ilişkileri-onlara dair düşünceleri ve müzik çalışmalarıdır. Özcan (1998) Merâgi'nin hayatına dair şunları söyler:

“Abdülkadir-i Merâgi (ö.838/1435): Ünlü Türk musiki nazariyatçısı, bestekâr ve icracı. Bugün İran sinırları içinde bulunan Güney Azerbaycan’ın Meraga şehrinde doğdu. Araştırmacılar 1350-1360 ylları arasında değişik tarihler verirlerse de henüz bunların hiçbiri itimada değer görünmemektedir... Doğduğu şehre nispetle Merâgi diye tanındı... Genç yaşta Meraga'dan ayrılarak Tebriz'e gitti. Burada musiki bilgisi ve kabiliyeti ile kısa sürede kendini tanıttı ve Celayir Hükümdarı Sultan Şeyh Üveys’in sarayına alındı... Şeyh Üveys'in ölümünden sonra tahta geçen Sultan Celaleddin Hüseyin zamanında da sarayda bulundu ve hükümdardan yakın ilgi gördü... Nevbet-i mürettep’in bestelenmesi hadisesi bu hükümdar zamanında olmuştur (11 Ocak 1377)... Sultan Hüseyin'in ölümünden sonra onun Bağdat'ta bulunan kardeşi Şehzade Ali'ye intisap etti... Şeyh Ali'nin saltanat mücadelesinde yenilmesinden sonra Celayir hükümdarı olan Sultan Ahmet Bahadır'ın himayesine girdi. 1386'da Timur'un Azerbaycan'ı zapt etmesi üzerine Ahmet Bahadır ile beraber Bağdat'a gitti... hâmisi Ahmet Bahadır'ı Mısır'a gitmek zorunda kalması, Merâgi'yi Maveraünnehir'e geçmek mecburiyetinde

2 Abdülkadir Merâgi’nin hayatı ve eserleri ile ilgili Nuri Özcan’ın çalışmaları dışında çok az çalışma vardır. Bunlardan biri Murat Bardakçı'nın Meragah Abdülkadir (Pan Yayıncılık, İstanbul 1986) adlı çalışması diğeri ise Yılmaz Öztuna'nın Abdülkâdir Merâğ î̀ (Kültür ve Turizm Bakanlığı Yayınları, Ankara 1988) adlı çalışmadır. 
bıraktı. 1398'de Timur tarafından verilen bir nişan ile Semerkant'a gönderildi. Timur'un veliahtı Glyasettin Muhammed Mirza'nın nedimi oldu. Timur'un ölümünden sonra tahta geçen Sultan Halil'in himayesine girdi... Sultan Halil'in iktidar mücadelesinde kardeşi Şahruh'a yenilmesinden sonra zamanın ilim ve sanat merkezi hâline gelmiş olan başşehir Herat'a geçti. Herat'ta özellikle Baysungur Mirza'dan yakın ilgi gördü. Daha sonra Şahruh'a intisap ederek sarayındaki meclislere katıldı. Herat'ta çıkan bir veba salgınında, yaklaşık seksen iki yaşında vefat etti ve orada defnedildi.”

Nuri Özcan’ın makalesinden yukarıya alınanlar Gecenin Yalnızhğında adlı romanda anlatılanlarla neredeyse örtüşür. Yani Selma Findıklı, onun gerçek hayatındaki kronolojiyi esas alan bir roman kurgusu yapar. Merâgi'nin, özellikle Celayir hükümdarı Sultan Üveys, Sultan Hüseyin, Sultan Ahmet, Timuroğlu Miranşah, Timuroğlu Giyasettin Mirza ve Timuroğlu Şahruh’la geçirdiği zamanda yaşadıklarına yer verir.

Merâgi’nin hayatının önemli dönemlerine odaklanan romanda kronolojik ilerleyen bir zaman vardır. Buna rağmen zaman zaman hatırlamalarla geri dönüşler olur. Gecenin Yalnızhğında 1373 yllında, Abdülkadir Merâgi 17 yaşında iken başlar; hatırlamalarla 1363'e kadar geri gider; 1435’te Merâgi'nin ölümü ile sona erer.

Romanın birinci bölümü: "Sahand Dağının Ötesi, Yaz 1373/Meraga" adını taşır. Abdülkadir Merâgi 17 yaşındadır. Meraga'da, nüfuzlu ailesi ve köle-hizmetçilerle dolu evinde mutlu bir şekilde yaşar. Merâgi'ye üç gün önce Celayir Sultanı Üveys'in kendisini Tebriz'deki sarayına davet haberi gelmiştir (s.26). Merâgi, sultanın daveti üzerine mecburen Tebriz'e gidecektir. Artık hayatının eskisi gibi olmayacağının farkındadır. İkinci bölüm, "Gönüller Bülbülü, Kış 1375/Tebriz" adını taşır. Bu bölümde Merâgi, Tebriz'de Sultan Üveys'le (s.33-38) ve Üveys’in oğlu Şehzade Hüseyin'le geçirdiği zamanları (s.40) anlatır. Merâgi saraya geleli iki sene olmuştur. (s. 38-41/44-48). Üçüncü bölüm, "Elf Leyle vü Leyle, Sonyaz 1386/Bağdat” başlıklıdır. Bu bölümde Celayirli Sultanı Ahmet Bahadır Han ve beraberindekiler, tabiî Merâgi de, Timur ordusuna yenilmiş ve Bağdat’a doğru kaçmaktadır. Merâgi on yıl kadar Bağdat'ta kalır ve ömrünün sonuna kadar evli kalacağı hanımı ile Bağdat'ta bir köle pazarında tanışır ve evlenir. Sultan Ahmet Bahadır Han Bağdat'ta eğlenceler düzenletir (s.73). Dördüncü bölüm, “Efrasyab Ülkesi, İlkyaz 1397/Semerkand” başlıklıdır. Merâgi Semerkant’tadır. Sokağa çıkıp atası olarak gördüğü Alper Tunga'nın izlerini arar. Semerkant Beyi, Timuroğlu Giyasettin Mirza ile Batı'da önemli başarılar kazanan ve bir devlet kurmuş olan Osmanoğulları üzerine konuşurlar (s.116-119). Son bölüm, "Gecenin Yalnızlığında, İlkyaz/1435 Herat" başlıklıdır. Merâgi artık Herat'ta, Baysungur Mektebinde hocadır (s.130). 1405 yılında yaşadıklarını hatırlar. Osmanlı Devleti 1402 yılında Timuroğullarına yenilmiştir. Timuroğulları Osmanlılara büyük acılar yaşatmıştır. Merâgi 1405 yılında Timur'a lanet okumak için ta Tebriz'e kadar gelen yaşlı bir Osmanlı dervişi ile karşılaşır ve onunla konuşur (s.131-136). Onunla konuşurken daha eski yaşadıklarını hatırlar. Tebriz'e ikinci gelişini, Tebriz Beyi olan Timuroğlu Miranşah'ın otuz üç yaşında aklını yitirmesi, Timur'un; Miranşah'ın aklını yitirmesini nedimlerine bağladığı için Miranşah'ın bütün nedimlerini, tabiî Merâgi'yi de, öldürmek istediğini öğrenmesi ile Tebriz’den ikinci kaçışını hatırlar. Merâgi, Timuroğullarına lanet eden bu dervişin lanetinin belki de kabul olduğu için Timuroğullarının başından felaketin eksik olmadığını düşünür.

Gecenin Yalnızhı̆ında kahraman bakış açısı ile yazılmıştır. Kahraman bakış açısı romandaki bütün olayların bir kahramanın gözünden ve değerlendirmelerinden hareketle anlatıldı ̆̆ı bir yöntemdir. Romanda tercih edilen anlatım tekniği ise bilin çakışıdır. Bilinç akışı tekniğini Sazyek (2004) şöyle anlatır: 
Living in a Palace Slavery or Happiness? The Novel Named Gecenin Yalnzzhğında Abdülkadir Merâgi’s Relationship with The Government Relations and Musical Work / N. Özmen (p. 59-73)

“...bilinç akışı tekniğinde düşünsel içerikli her bir cümle başlı başına bir bütünlüğe sahiptir. Dolayısıyla bilinç akışında cümleler arasında bir anlam kopukluğu, gevşekliği söz konusu olur. Zihnin serbest işleyişinin bire bir metne dönüştürümü olarak tanımlayabileceğimiz bu uzaklı̆ı̆ yaratan temel öge ise çağrışım olur. Bir düşünce, bir başkasını çağrıştırır, o da ötekini. Figür, birbiriyle ilgisiz görülen düşüncelerini her bir cümlede anlamsal sıçramalar, atlamalar yaparak sıralar. Bunda da iç konuşmada olduğu gibi, hatta ondan daha yoğun ölçüde, imge kullanımı söz konusudur. Düşüncelerin yanı sıra dış gerçekliğe ait nesnelerden, motiflerden bilinçaltına ait düşlere kadar varan geniş bir dağarcık, öznelleştirilerek özel kılınmaya elverişlidir bilinç akışı tekniğinde. Böylece insanın iç gerçekliği ve dış dünyayı, hayatı algılayışının boyutları önceki teknikten daha uç noktalarda, olanca açıklı̆ıı, derinliği hatta çarpıklığıyla ortaya çıkarılmış olur.”

Gecenin Yalnızhğında adlı romanda okuyucu romanın başından sonuna kadar Abdülkadir Merâgi’nin bilinci üzerinden, yani bilinç akışı tekniği ile olayları görür ve değerlendirir. Diğer kahramanlar sadece konuşmaları ile ve zaman zaman romana dâhil olur.

\section{A. Meragi Sultan Saraylarinda}

\section{Meraga'dan Ayrılık: Yöneticilerle Tanışma}

Abdülkadir Merâgi, Meraga'da ailesi ile mutlu bir şekilde yaşarken kendisini Tebriz'e, Celayirli sarayına davet etmek için saray habercileri gelir. Kendisine sultanın davet 3 haberini getiren gümüş mahmuzlu çizmeli, kulaklarında saraylı olduklarını belli eden küpeli askerler şöyle derler:

"Meraga şehrinde Glyasettin Gaybî namında ünlü bir hafizın hünerli bir oğlu olduğunu işitmiş şahımız. Hem sazı hem sözü dahi üstünmüş cümle yaşıtlarından. Üveys Han fermanıdır bu. Abdülkadir İbni Gaybî̀ye bundan sonra sarayında yol gösterilsin diler.” (s.22).

Doğu dünyasında sultanların bilim adamı, sanatçı ve düşünürleri sarayına davet etmesi çok köklü bir gelenektir. Halil İnalcık (2013, s.10) Şâir ve Patron adlı eserinde bunu şöyle ifade eder:

“Orta-Doğu’da da, bir hükümdar için en şöhretli bilgin ve sanatkârları sarayına çekebilmek gerekirse onları zorla alı getirmek olağan bir şeydi. Timur istila ettiği her memlekette en şöhretli bilgin ve sanatkârları toplayıp Semerkant’a götürmüş, Yavuz Selim Tebriz ve Kahire’yi aldığında yüzlerce sanatkârı İstanbul'a sürmüştür.”

Çünkü saray, yönetimin olduğu gibi çoğu zaman sanatın da merkezidir. En güçlü sanatçllar sultan saraylarında bulunmak için çeşitli yöntemler denerler. Örneğin hem Arap hem Türk hem de Fars hükümdarlarının dikkatini çekmek için şairler sultanlara kasideler sunarlar. Çavuşoğlu (1986), Kaside adlı makalesinde kasidelerin niçin yazıldığını ve kaside yazan şairin ne beklediğini şöyle anlatır:

"Kaside; sultanın cesaretinin, adaletinin, cömertliğinin, zekâsının, bilgeliğinin propagandası idi. Halkın erdem olarak bildiği ve değer verdiği ne varsa onların eksiksiz olarak en mükemmel şekilde sultanda bulunduğu hem de büyüleyici bir eda ile anlatılıyordu. Şair, medhiyye bölümünde sultanlık, vezirlik, müftülük örneği yüksek makamlardan birinde bulunan kişinin o makamın gerektirdiği

3 Çağan (2004, s.79), Sanat ve Edebiyatın Toplumsal Perspektifi-Siyasal İlişkilerine Dair Genel Bir Çözümleme başlıklı makalesinde, yöneticilerin yanlarında niçin sanatçlları da görmek istediklerini anlatırken şunları ifade eder: "İktidar kendi sürekliliğini sadece güç kullanımına endekslemez; beraberinde kendi gücü karşısında rıza gösterenleri de görmek ister. Bu yönde rızayı temin etmede manevi kültürel ögelerin bütününden yararlanır. Çünkü toplumun rızası üretilen bir şeydir. Bu elbette sanatın ve edebiyatın, rızanın gerçekleştirilmesindeki önemine dikkat çeken bir durumdur.” 
erdemlerin en yücesine sahip olduğunu söyler, böylece onu övmüş, fakat diğer taraftan o erdemlere gerçek anlamda sahip olmaya da teşvik etmiş olurdu. Bunlar adalet, bilgelik, eli açıklık, düşkünleri korumak, sanat ve bilim adamlarına el uzatmak, merhamet, cesaret gibi her türden idarecide bulunması mutlak olarak gerekli niteliklerdi."

Çolak ve Hilooğlu (2010, s.89-90), Osmanlı İktidar Anlayışı Çerçevesinde Şïr adlı makalelerinde:

“İktidar; kendini meşrulaştırmak, meşruiyet düzeyini yükseltmek, görkem ve gücünü göstermek açısından sanata ve icracılarına duyduğu ihtiyacı gidermek için gücünü kullanarak değişik eylemlerde bulunmuştur. Sadece içte değil, hâkimiyet alanı dışında da bu gücü göstermek amacıyla sanatçları mekânına davet etmiş, mükâfat ve iltifatlarla çalışmalarını desteklediğini göstermek istemiştir. Özellikle de Doğu toplumlarında çok güçlü olarak hissedilen “gelenek” ve “din” kavramlarının varlığı, sanatın bu kavramlar dâhilinde kendini ifade etmesine, sanata kutsallı ögesinin eklenmesine ve dinsel bir yönü bulunan iktidarla iç içe olmasına neden olmuştur.”

der. Sanatın niçin himayeye ihtiyaç duyduğunu şöyle anlatırlar:

"Sanat eserlerinin geniş kitlelere ulaşması ve sanatçlların günümüzdeki gibi eserlerinden geçimlerini kazanmaları mümkün olmadığından sanatçının yaratısını değerlendirecek bir hâmi şart olmuştur.” (s.91).

Merâgi'yi Tebriz'deki saraya, bir anlamda hâmisi olacak sultanın yanına4 davet eden haberciler: "Çatık kaşlı, kimi biraz yumuşak bakışlı, ama hepsi bir cellat kadar karanlık yüzlüdür” (s.5). O, Meraga'dan ayrılmadan önce üvez ağacından bir çalgı yapmak ister. Fakat bir günde bunu yapması mümkün değildir. Çünkü ertesi gün yola çıkacaktır. İçinden şöyle bir düşünce geçer: "Tebriz’in bahçelerinde üvez var mıdır bilmem. Varsa bile sultan izin verir mi dilediğim sazı yaratmama” (s.6) Merâgi Tebriz’i düşünür. Artık hayatının eskisi gibi olmayacağının farkındadır, zihninden şunları geçirir:

"Ne buyrulursa onu çalmak ne arzu edilirse onu söylemek zorundayım bundan sonra. Bir göz kırpması ile darağacına gönderebilir, bir parmak oynatması ile çil çil altınlara boğabilir beni yaldızlı kerevete oturan adam..." (s.6).

Merâgi, Meraga'da o kadar farklı ve zengin bir ses dünyasının içindedir ki bunların hepsini hiç silinmeden Tebriz'e götürmek ister. Ama bir endişesi vardır. Acaba hâmisi olacak sultan yapacağı besteleri beğenecek midir? (s.23). Bir ara Tebriz’e gitmemeyi düşünür ancak bu mümkün değildir. "Yazgımda kara günler olduğunu söyleseler vazgeçebilecek miyim Tebriz’e gitmekten? Öyle de ölüm

$4 \quad$ Akengin (2014, 147-148), Sanat İdeoloji Politika İlişkileri adlı makalesinde hâmileri tarafından korunan sanatçının hâmisini eleştiremeyeceğini ifade eder: "Rönesans'ı tetikleyen etkenlere bakıldığında, sanatçıları koruyan "mesen”ler ya aristokratlardan, ya hanedanlardan bazen de feodallerden çıkar. Sanatçııı destekleyen bu tür şahsiyetlerin hangisi desteklenen sanatçı tarafından eleştirilmeye izin verebilirdi? Hatta kendilerinin sanatçlar tarafindan pohpohlanmaları gibi beklentileri olmadığı söylenebilir mi? İnsan doğası yönünden ele aldığımızda bu sorulara olumlu cevap vermek biraz zor görünüyor" der (s.145). Yazısının devamında Osmanlı tarihini örnek gösterir. Osmanlı'da sanatçların bağımsız olamayacağını şöyle ifade der: "Padişahların ve diğer devlet adamlarının ressamlara nakkaşlara, şairlere, müzikçileri, hattatlara "ihsanlarda bulunmuş" olmaları gerekir. Bu "ihsan"larda bulunan padişah ve diğer devlet adamlarının hangileri kendilerinin o sanatçlar tarafından olumsuz eleştirilmeye açık oldukları söylenebilir?” der (s.145). Rusya'dan da örnek verir: "Marksizme eleştirel gözle bakan hangi sanatçıyı sistemin desteklemiş olduğu söylenebilir?... O hâlde bu örneklerden hareketle diyebiliriz ki, soyut anlamıyla sanatta bağımsızlık ne kadar ideal olsa ne kadar savunulursa da somut dünyada birebir karşılık bulamıyor." (s.146) Asıl hakikati ise şöyle ifade eder: "Sanatçının hayatını sürdürebilmesi için desteklenmeye ihtiyacı vardır. Aksi hâlde sanatını geliştiremez, sürdüremez. Hiçbir destek de sistemler ve kişiler tarafından, kayıtsız şartsız, bir yarar beklemeksizin sunulmaz... Komünist de Demokrat da olsa, her devlet siyasi ve zorlayıcı güçleri bünyesinde barındırır. Devlet kaynakları ve güçleri kontrolü elinde tutan gücün çıarlarına hizmet etmek ve devleti tehdit eden şeylerle meşgul olmak üzere kullanmaya meyillidir.” 
Living in a Palace Slavery or Happiness? The Novel Named Gecenin Yalnızhğında Abdülkadir Merâgi’s Relationship with The Government Relations and Musical Work / N. Özmen (p. 59-73)

demektir, böyle de " (s.23) diye geçirir içinden. Sultan Üveys'in yumuşak huylu olduğunu işitmiştir ama yine de çok endişelidir. Onun kanlı bir zalim olduğuna inanır (s.31). Hiçbir şekilde bu daveti reddedemeyeceğini bilir. "Üzerimde bu korku varken nasıl Tebriz'e gidip sultana besteler, şiirler sunabilirim; soluğumu ne zaman keseceğini bilmeden.” (s.32) diye düşünür. Gecenin Yalnızhğında adlı romanın başkahramanı Merâgi, birçok sanatçının aksine sultan sarayına gitmek ve orada bulunmak istemez. $\mathrm{O}$ aslında hürriyeti tercih eder, istediği eserleri istediği zamanda ve istediği şekilde bestelemek ister. Ancak buna gücü ve imkânı olmadığını çok iyi bilir. Sultanın arzusunu yerine getirmek ve saraya gitmek zorundadır.

Merâgi, Meraga'dan ayrılmadan önce Kıpti çocuklara rastlar. Kıptilerin kendilerini, Mısrî ya da İskenderî olarak tanımladıklarını bilir. Onların Firavunlardan kalma tılsımlar taşıyıp taşımadıklarını düşünür (s.7). Kıpti çocukların çömleklere vurarak çıkardıkları seslere çok şaşırır: "Telsiz yaysız, burgusuz, mızrapsız sazlar yapabiliyor bu hünerli insanlar. Her an her yerde her nesne ile... Aynı sesleri daha zenginleştirebilir, perdelere ayırabilirim" (s. 9) diye düşünür. Bu, onun hayatının her anındaki seslere değişik bir dikkatle yaklaştığını ve onları değerlendirmek üzere zihninde topladığını gösterir.

\section{Tebriz'de: Celayirli Sarayında Korkular}

Merâgi, Tebriz'e Sultan Üveys'in sarayına varır ve sarayda onun nedimi olur. Sultanla saraydaki cam odada söyleşirler. Merâgi, Sultanın yanında son derece ürkektir ve her sözü iyice düşündükten sonra ancak söyleyebilir, zaten çok konuşamaz. Çünkü sessizlik olduğunda onu ancak Sultanın bozabileceğini bilir. Sultan, arada enfiye çekerek, gürültülü hapşırması ile yüzüne tükürükler saçarak Merâgi’ye bir şeyler çalmasını söyler. ${ }^{5}$ Merâgi hemen sazını eline alır ve uzun zamandır kafasında paramparça gezinen sözler: "sultan karşısında can korkusuyla ayağa dikilen bitkin tutsaklar kadar hızla sıralanır." (s.35).

Abdülkadir Merâgi sarayda kendisini tutsak edilmiş biri gibi görür. Çünkü iki yıldır Sultan Üveys anne ve babasını görmesine ancak bir kez izin vermiştir (s.37). Gözünün önünde dövülen esirler canlanır. Kendisini de bir esir olarak görür. Çünkü o da bestelerini sultana beğendirmeye çalışan bir köle gibidir. Dışarıdan bakıldığında saraydaki sanatçının mutlu olduğu düşünülebilir veya saraydaki bir sanatçının hayatını anlatan romancının onun mutluluğunu tasvir etmesi beklenebilir. Oysa Merâgi kendisini, istendiğinde kullanılan istenmediğinde bir köşede unutulan saray kölesi gibi görür.

Abdülkadir Merâgi sarayda Sultan Üveys'in oğulları Şehzade Hüseyin, Ahmet Bahadır ve Ali'den de çok çekinir, korkar. Çünkü onlara da bir gün taht sırası gelecektir. Merâgi sık sık ecelinin hangi şehzade elinden olacağını düşünür. Bir gün en büyük şehzade Hüseyin'le dışarıda dolaşırken karlar üzerinde bir ölü kuş bulurlar. Bunun üzerine Merâgi: "Ya beni nasıl bir son bekliyor? Ansızın hançerle mi gelecek ölüm? Yoksa darağacına çıkacağım günü bir zindan da mı bekleyeceğim?” (s.39) diye aklından geçirir. Yolculuk uzun sürünce Merâgi endişelenir ve şunları düşünür:

“Ayazlı havada epey yürüyeceğiz. Akla gelmedik sorular soracak. Ben de bıkkınlık göstermeden yanıt
bulacağım hepsine. Hoşuma gitsin ya da gitmesin... Sonra yavaş yavaş geri döneceğiz. Ama o
isteyince... Soğuktan katılmış bedenim alevleri yedi başlı canavarın dilleri gibi uzayıp kısalan ocak
önünde gevşemeye fırsat bulamadan udu verecek kucağıma. Çalmamı hem de öğretmemi buyuracak.
Babası da öyle yapmıyor mu? Keyifsizliğimi açığa vuramam... Gönlümün darlığını belli edemem...

5 Sağlık (2004), Edebiyatta Bağlanma Sorunu adlı makalesinde Yakup Kadri Karaosmanoğlu'nun şu ifadelerini aktarır: "Sanat kadar sanatkâr da hürriyet-i kâmileye muhtaçtır. Bir şaire: Sen şunu teganni edeceksin demek, bir romacıya: Sen filan ve falan muhitleri, falan ve filan insanları tasvir et! Emrinde bulunmak; mavi gözlü bir kimseye "senin gözlerin siyah olacak öyle yap!" demek kadar gülünç, abes, gayr-i tabii bir istibdâd-ı fikrîdir." 
Ölüm var ucunda” (s.40) “....acep hangisi olacak celladım? Ne kadar zamanım kaldı. Hüseyin’den sonra Ahmet Bahadır’n hükümdarlığını görmeye ömrüm yetmeyecek sanki... Sıcak bir ter boşanıyor tepemden tırnağıma” (s.41).

Merâgi'nin babası Giyaseddin Gaybî çok önemli bir ilim ve sanat adamıdır. Merâgi’ye göre babası da tıpkı kendisi gibi bir esirdir. Çünkü o da sultanlara hizmet etmiştir. Merâgi, hizmetçi-efendi ilişkisine dair şunları düşünür:

"Beylerden, sultanlardan çağrı gelip de babamın Kuran okumak ya da musiki öğretmek üzere huzura çımadığı, taht öpmediği görülmüss müydü hiç? Hasta olduğunda, yorgun düştüğünde bile... Ben de aynı yazgıyı paylaşmak için yetiştirilmekteydim. Öyleyse ne farkımız vardı tarlalarımızda çalışan rençberlerden" (s.43-44).

Şehzade Hüseyin'le çıtıkları gezintiden dönerken şehzadenin gittikleri izler üzerinden dönmek istemeyişi dikkatini çeker ve bunu şöyle değerlendirir: "Her defasında başka yığınları ezmekten, çürütmekten hoşlanıyor sanki... Bir şehzade de böyle mi hazırlanır tahta çıkmaya? Zulmetmeyi öğrenerek" (s.44). Bir ara şöyle düşünür:

"Doğrusu sultan Üveys Zalim bir hükümdar diyemem ama söyleşirken, fasıl dinlerken gerçek yüzü belli olur mu insanoğlu'nun? Savaşta nasıl can alıcıdır kim bilir? Belki yaralı düşman askerlerine bir yudum su verdirmeyecek kadar... Ya da son kılıç darbesi ile ölüme gönderecek kadar” (s.44).

Merâgi, zalim idarecilerin arasında kendini bir esir gibi görmeyi sürdürür: "Gök kubbede parıldayan yıldız gibi genç yaşta herkesi kıskandıracak saygınlığa erişmiş olsam da ayaklarım buyrukla yön buluyor. Kula kulluk değil de nedir bu?” (s.44) diye kendi kendine sorar.

Sultan Üveys hastalanır, ölmek üzeredir. Bu durum karşısında Şehzade Hüseyin çok katı görünür. Merâgi şöyle düşünür:

"Belki de üzülmüyor değil babasının durumuna... Belki öleceğini de aklına getiriyor... Ama soyluluk böyle katı davranmasını gerektiriyor. Devletin dirliği için odalara kapanıp gözyaşı dökmek yakışmıyor hükümdar ailesine. Ben de olsam ne yaparım diye kendimi sorguluyorum” (s.48).

Sultan Üveys vefat eder. Oğlu Şehzade Beyazıt daha çocuk sayılacak yaşta olmasına rağmen cenaze töreninde sert bir kaya gibi kıpırtısız durur. Merâgi, bunun üzerine sultan ailesine dayanıklılığın yakışacağının çok iyi öğretilmiş olduğunu düşünür (s.49).

Şehzade Hüseyin Celayir, sultanı olur. Merâgi ailesini iki senedir görememiştir. Ailesini görmek için yeni sultan olan Hüseyin'den izin almak ister ama çekinir. İzin istemesini, Sultan Hüseyin’in, yanında kalmak istemediği için bahane gibi kullandığını düşünmesinden korkar, izin isteyemez. Bir süre beklemeye karar verir. Onun tahtına bağlı kalacağına Sultanın kanaat getirmesini bekler (s.49). Giyaseddin Gaybî̀nin oğlu olarak, sıradan biri olarak yaşamış olsa Tebriz'de ve sevdikleri ile beraber olacağını düşünür. Sarayın parıltısını aile ocağına yeğlediği için kendine kızar. Zaman zaman, Sultan Üveys öldü, ecelim galiba Sultan Hüseyin’in elinden olacak diye aklından geçirir (s.50).

Bir gün 17 yaşındaki Sultan Hüseyin bir meclise girdiğinde hanende ve sazendeler dâhil herkes ayağa fırlar. Merâgi’nin bedenini garip bir ürperti sarar. Ürpermesinin sebebini şöyle açıklar: "Yazgımın şu iki 
Living in a Palace Slavery or Happiness? The Novel Named Gecenin Yalnzzhğında Abdülkadir Merâgi’s Relationship with The Government Relations and Musical Work / N. Özmen (p. 59-73)

dudak arasında son bulabileceğini düşündüğümden olsa gerektiç” (s.64). Merâgi sarayda hep ölme, öldürülme, eleştirilme, ötekileştirilme korkusu ile yaşar.

Merâgi'nin hanende ve sazendelerle birlikte Sultan Hüseyin'in huzurunda söylediği şarkılardan sonra Sultan ve maiyeti çok mutlu olur. Sultan bir nedimine emir vererek Merâgi'nin başından altınlar saçtırır. Merâgi etrafındakilerin takdir edici bakışlarını hisseder ama o bakışlarda samimiyet bulmaz. Diğer müzisyenlerin kendisini kıskandığının farkındadır. Sarayda etrafında bulunanlar tarafından çok takdir edilmesi Sultan tarafindan övülmesi bile Merâgi’yi mutlu etmez (s.52-53).

Bir gün sarayın cam odasında Sultan Hüseyin ile Merâgi sohbet eder. Sultan ona: "Ecel kimden gelir ey ustam?” der. Bunun üzerine Merâgi: “Tanrı'dan elbet sultanım” der. Sultan: “Tanrıdan önce davranmak isteyenleri görmez misin?" der. Merâgi: "Kimdir o kendini bilmez, Hak’tan korkmazlar" der. Sultan, öz kardeşlerini kastederek: "Ahmet Bahadır... Dahi Ali... Dahi Beyazıt” der. Bunun üzerine Merâgi onların çocuk olduğunu söylese bile sultanı ikna edemeyeceğini bilir. Çünkü taht kavgalarının yaşa bakmadığını, hele vezirlerin, nedimlerin kışkırtmasıyla boyu kısacık şehzadelerin aslan kesildiğini kimsenin yadsıyamayacağını bilir. Bir ara kendi kendine itiraf eder: "Fasıl meclislerinde yan yana sıralanmış üç kardeşin bakışlarında gizli hevesler parıldadığından kuşkulanmamış mıydım?” (s.57). Merâgi tekrar ecelinin hangi şehzade elinden geleceğini düşünür (s.57).

Merâgi Sultan Hüseyin ile sohbet ederken bazen onun beklediği cevapları veremez. Bu Merâgi'yi: "Çalıp söylemekten, gönlünü eğlendirmekten başka bir işe yaram(ıyorum)” (s.58) düşüncesine sevk eder.

\section{Bağdat’a Doğru: Korkular Yine Aynı}

Tebriz, Timur tarafından işgal edilir. Celayir Sultanı Ahmet Bahadır adamları ile, tabii bunların içinde Abdülkadir Merâgi de bulunur, Celayirlilerin ikinci önemli şehri olan Bağdat’a doğru kaçar. Bu sırada Merâgi şöyle düşünür: "On dört yıldır kafamın içinde sık sık kurulan darağacı bozulmadı ki... Yalnız Azrail'in adı değişti bu kez. Sultan Üveys ya da Hüseyin ya da Ahmet Bahadır değil, Kazan Han damadı Timur" (s.59). Timur'a yenilen ve ondan kaçarak Bağdat’a doğru ilerleyen Ahmet Bahadır, Bağdat’a muzaffer bir komutan gibi girmek ister. Otuzuna gelmeden ihtiyarlık alametleri gösteren Sultan Ahmet Bahadır'ın vicdanı olup olmadığını düşünür. Çünkü o, tahtı ele geçirme uğruna ağabeyi Hüseyin’i öldürmüş, en küçük kardeşi Beyazıt'ın gözlerine mil çektirmiştir. Durum bu iken onun masum görünüşüne hayret eder. Merâgi taht kavgaları sebebiyle acıların yaşanıp yaşanmaması gerektiği konusunda mütereddittir (s.61). Kendi kendini de çok eleştirir:

\footnotetext{
"Sultan Üveys öldükten sonra -Hüseyin'in haklı hükümdarlı̆̆ı dışında- tam bir kargaşa devri başlamış; birbirinin gözünü oymakta kararlı dört şehzade hangi yana savrulmuş, kaç günlüğüne taç giyebilmişse, ben de onun önünde diz çökmemiş miydim? Ahmet Bahadır’a karşı Ucan savaşında zafer kazanıp onu Bağdat’a gönderen kardeşi Ali adına kırk dokuz zamanlı "Darb-Fetih” usulünü yapan da benim; Ahmet Bahadır Tebriz'e döndüğünde hemen eteğini öpen de. Kılı̧ kimdeyse Meragalı Abdülkadir İbnî Gaybî de onun gölgesine sığınmak zorundaydı çünkü. Ben istemeden yolumu böyle çizmişti Tanrı... Keşke sesim güzel olmasaydı. Babam Kuran’ı nağmelerle okumayı öğretmeseydi. Ünüm Meraga’yı aşıp Tebriz Sarayına ulaşmasaydı” (s.61-62).
}

Bunlar bir sarayda iktidar sahipleri ile mutluluk içinde yaşadığı hayal edilen sanatkârın vicdan muhasebesi ve oradaki mutsuzluğunun ispatı durumundadır. Merâgi, Sultan Ahmet Bahadır ile beraber Bağdat'a girmek istemez. Fakat başka seçeneği yoktur. Diğer kullar gibi o da Bağdat'a sultanla beraber 
girecek, hiç görmediği bir sarayda yabancı bir yastığa baş koyacak, doğacak günü istemese de güler yüzle karşllayacak, Timur'dan hiç söz açamayacaktır. Oysa Merâgi:

"Hükümdarın nedimi olarak zengin sofralara oturmaktansa, Sahand Dağ’nın yamacında sürüsünü otlatıp bayat ekmek, küflü peynirle karnını doyuran yoksul bir çoban olmayı yeğlediğini açığa vuramaya(cak), sazların hiçbirine dokunmak istemediğini bildiremeye(cek) ” tir (s.68).

Merâgi'nin duygu âlemi böyle olduğu hâlde kendisinden devamlı yeni besteler beklenecek, yeni bestelerusuller yapması istenecek ve o bunlar karşısında sadece "başım üstüne sultanım" diyecektir (s.68).

\title{
4. Bağdat'ta Çile-Umut: Sultan Ahmet Bahadır/Necm-i Hindî
}

Merâgi, Bağdat'ta sokakta Feramuş adlı biriyle karşılaşır. Sohbet sırasında Feramuş, Merâgi'nin ne iş yaptığını öğrenince Merâgi'ye şöyle der: "Sultan soytarısı sayılırsın bir bakıma...'Çal' dediğinde çalmak, 'Sus' dediğinde susmak zorundasın (s.77). Merâgi, Feramuş'a: "O kadar da küçümseme, zengin besteler de yaparım ben... Kimsenin görmediği, sesini işitmediği yeni çalgılar” der (s.78).

Merâgi, Feramuş'la Bağdat esir pazarına gider. Esirlerin hâlini görünce onlara acır (s.80). Feramuş, satın almak üzere esirler arasından çocuklu bir kadını seçer. Aynı kadını Merâgi de beğenir. Pazardaki köle kadını, 10 yaşında iken Tebriz esir pazarında gördüğü esmer güzeline benzetir (s.87). Feramuş’tan köle kadını kendisine bırakmasını ister. Bu arzusunu Feramuş’a söyleyene kadar çok sıkıntı çeker. Merâgi'ye göre bu sıkıntısının sebebi şunlardır:

\begin{abstract}
“17 yaşımdan beri sultan buyruğu altında yaşamak kişiliğimi öldürmüş, korkaklaştırmış âdeta. Ahmet Bahadır Han, muhafızlarını ardıma salmadan şehri dolaşmama izin veriyorsa da aklıma esen her şeyi yapamam” (s.84). "Neden konuşamıyorum? Zalim hükümdarlar tarafından dili kesilmiş lâl köle gibi... Yok, gibi değil, gerçekten öyleyim... Sultanların hoşça vakit geçirmesi için ekmek yedirilen bir soytarıyım... Bugüne kadar hiçbir isteğim olmadı hizmet ettiğim kişilerden” (s.86).
\end{abstract}

Merâgi esir pazarında gördüğü esir kadını satın almak ve saraya getirmek istediğini Sultan Ahmet Bahadır'a söylemek ister. Bu sebeple onun keyfinin yerinde olduğu bir anı kollar. Eline udunu alır, düyek usulünde bir nakış besteye başlar: "Karşımda oturan yenik hükümdar, kardeşlerini öldürebilecek gözlerine mil çektirebilecek acımasızlıkta olsa da, benim derdime derman bulacak” (s.89) diye düşünerek zihnen iyice hazırlanmasına rağmen Sultan Ahmet Bahadır'a esir bir kadın satın almak istediğini söylemeye cesaret edemez. Derdini dile getirmek için yaptı̆̆ım Rast beste bile ağır bir yük gibi omzuna çöker (s.90). En sonunda Sultana, sevdiği kadının esir olduğunu söyleyebilir. Sultan esir pazarına gitmiş olmasını yadırgayınca Merâgi: "Kulağım değiş̧ik sesler aramaktaydı... Çarşıda dolaşırken o zavallıların satıldı̆̆ı yere götürdü beni ayaklarım” der (s.91). Niçin esir pazarına gittiğini böylece açıklar ve rahatlar. Fakat esir kadını anlatırken çok sıkıntı çeker, ezilir, büzülür. Şöyle düşünür:

“Cesaretim olsa geri dönmemek üzere sarayından kaçıp gitmek istiyor gönlüm. O da yetmiyor; Timur'un karınca sürüsüne benzeyen ordusuyla Tebriz’i fethettiği gün onu öldürmediğine yazıklanıyorum. Kapısında nimet bulsam da nefret ediyorum şimdi Ahmet Bahadır'dan... Üstelik köle de değilim ben. Bunca hünerim varken nerede olsa bir dilim ekmek verilmez. Necm-i Hindî̀yi de (esir kadın-N:Ö) alırım yanıma... Sağ bırakılırsam eğer.... Zâlim hükümdarın askerleri gün kavuşmadan yakalayıp öldürür ikimizi de.” (s.93). 
Living in a Palace Slavery or Happiness? The Novel Named Gecenin Yalnzzhğında Abdülkadir Merâgi’s Relationship with The Government Relations and Musical Work / N. Özmen (p. 59-73)

Sultan Ahmet Bahadır, Merâgi'nin esir kadını almasına izin verir, fiyatının ne kadar olduğunu sorar. Çünkü parayı kendi hazinesinden ödeyecektir. Merâgi buna gerek olmadığını çünkü yıllardır zaten Sultandan nimetlendiğini ifade eder. Bir an bu düşüncesinden vazgeçer. Birikmiş olan parası Sultan Ahmet Bahadır hazinesinden sağlanmış olsa bile kendi emeğinin karşılığıdır. Bu düşünce onu rahatlatır. (s.94).

Ahmet Bahadır’, iri gövdesi ile odadan dışarı çıkarken gören Merâgi şöyle düşünür: "İpek çarşaflar serili kabarık yatağında kim bilir hangi narin bedeni ezip tiksindirmek üzere çıkıyor dışarı.” Bu düşüncesi, onun başından beri yanında bulunduğu sultanların tamamına karşı olan eleştirel tutumunun bir örneğidir. Sultan Ahmet Bahadır yatmaya gidince o da hemen udunu alıp yatmaya gider. Çünkü sultan uykuya dalınca adeta soytarısı olan Merâgi’ye kimsenin hizmet etmeyeceğinin farkındadır (s.94).

Merâgi saray hayatının sahteliğini şöyle anlatır:

"Saltanat otağında her şey sahte... Her şey yalan... Aynada yansıyan hayaller gibi silinip gidiyor zamanla... Bugün sırmalı elbiseler, yaldızlı börkler takabilenler yarın darağacını boyluyor. Kimse gönlünden geçenleri açıkça söyleyemiyor. Dilediğini yemek, hoşlandığın yere gitmek hakkı da yok. Çalmak, söylemek istemediğin anlarda bunu dile getiremiyorsun, hükümdarın başına taç olmak neye yarar. Devletlilerin kulağına hoş ezgiler gönderdikçe el üstündeyim. Onlar beni dinlemekten zevk aldıkça övgülere, altınlara boğulurum. Ötesi karanlık bir kuyu" (s.94-95).

Merâgi 1500 dinarı ödeyerek esir kadını satın alır (s.98). Ahmet Bahadır’ın esir kadına ilişmesinden korktuğu için, onu bir süreliğine Feramuş'un Dicle kıyısındaki konağında bırakır (s.99). Bu onun korkusunun büyüklüğünü göstermesi bakımından önemlidir.

\section{Semerkant da Son Değil: Gyyasettin Mirza Muhammed'le}

Timur'un ordusu Bağdat'ı da işgal eder. Merâgi ve diğerleri Bağdat’tan Mısır'a doğru kaçar. Merâgi Kerbela'da Timur'un oğlu Miranşah'a yakalanır. Öldürülmekten çok korkar: "Yenik düşmüş Celayir Sultanına hem de ondan önce babasına, kardeşlerine hizmet etmişliğim en büyük suç olmalıydı Timur’un gözünde. Nasıl bağışlasındı böyle birini?” (s.107) diye düşünür. Bir yandan: "Ne Ahmet Bahadır ne Timur fazla umurumdaydı açıcçası. Delikanlılık çağlarından beri başıma gelenler hep sultanlar yüzündendi. Borçlu değilim onlara" (s.106) diyerek kendini teselli eder. Abdülkadir Merâgi kendi yeteneklerini düşünür. O güne kadar besteleri ün kazanmış, kimsenin görmediği sazlar yapmış, yeni makamlar icat etmiş, hiç kullanılmamış usuller bulmuş, sultanların has nedimi olmuştur. Karşılı̆̆ında, hükümdarlar neredeyse canını bile almıştır. Merâgi, Timur'un huzuruna çıkarılır. Orada darağacına yaklaştığını hisseder. Tahtından kendisine iğrenerek bakan Timur'u şiirleriyle övmek zorunda kalır. Bunu, ruhu ve benliğinin ölümü olarak görür (s.108). Timur tarafından bağışlanır hatta Timur ona koca bir konak hediye eder. Merâgi, Semerkant’a gelir. Şöyle düşünür.

“Taş üstünde taş kalmamacasına defalarca yerle bir edilen bu vadi şehrini kendime benzetiyorum. Süslü elbiseleriyle Arap atlarına binmiş emirberler eşliğinde Meraga'dan Tebriz’e Sultan Üveys’in sarayına gittiğim günden beri kaç devletliye hizmet ettimse hepsinin yazgısını paylaşmak zorunda bırakılmadım mı? Türkistan'dan Bağdat'a; oradan Maveraünnehir'e sürüklenirken de bana bir şey soran olmadı; ödüllendirilip cezalandırılırken de. Timur ordusu Celayirlileri diyardan diyara kovdukça hükümdarın eteğine tutunarak yaşayan Hafız İbni Gaybî de savruldu yel sırtında” (s.103). 
Artık Merâgi’nin sazına buyruk veren Timur'un hayatta olmayan büyük oğlu Cihangir’in oğlu, hem de hanedanın göz bebeği, Glyasettin Mirza Muhammed'tir. Oğlu yaşındaki şehzadenin eteğini öpmek Merâgi'nin gönlünü incitir ama aklı ona şunu söyler: “Devran böyle gerektiriyorsa Giyasettin’in efendiliği gocundurmasın seni” (s.112). Merâgi bu hâle de alışır. Glyasettin Mirza Muhammed'e rastgele yapacağı bir beste vermek ister ama hemen aklına şu gelir:

“Öyle ya acıları kabullenmeyi -doğrusu vurdumduymazlığı-öğrenmiştim ben. Kendimce yaşayacağım bir hayatım olmadığını da. Meraga'dan ayrıldığım sabah yitirdiğim özgürlüğün asla geri verilmeyeceğini de. Sultanların istemine göre hareket edeceğimi de" (s. 114).

Glyasettin Mirza gönlünü eğlendirmesi için Merâgi'yi çağırtır. Merâgi o anda hanımı İkbal'le hoş vakit geçirmektedir. Ancak: "Gül yüzlü sevdiğimi bırakıp gitmek zorundayım. Sultanların acımasızlığını bilmiyor değilim ki” der (s.116). Merâgi Sultanın huzuruna varınca Sultan kendisi için söz verdiği usulü ne zaman yapacağını sorar. Merâgi, Glyasettin Mirza Muhammed'e beklediğinden daha iyisini; iki yüz vuruşlu bir devir yapacağını söyler. Bu sırada Gıyasettin Mirza Muhammed kızar: "Sabrım yoktur beklemeye.” der ve elindeki sarı çiçeklerden birinin daha boynunu kopartır. Merâgi endişelenir, şöyle düşünür: "Zevkine zevk katmada başka canlar yakarken” (s. 119).

\section{Herat'ta: Huzurlu Sona Doğru}

Merâgi artık Herat’tadır ve saray mektebinde musiki dersleri verir. Hanımı ve çocukları ile mutludur. Çocukları Nureddin ve Nizameddin büyümüştür. İkisinin ortak yönü hünerde babalarını aratmayacak olmalarıdır. Ancak çocuklarının bu mahareti Merâgi'yi çok memnun etmez:

"Sıradan kişiler olamazlardı. Benim çocuklarımdı onlar. Boşuna mı baş tacı edilmiştim saraylarda? Bunca yıldan sonra biraz övünsem ayı mıydı? Gözlerimin ışı̆̆ı Nureddin’i de bilgiyle donatacak, herkesten farklı kılacaktım. Peki niçin? Başka sultanların kölesi olup diyardan diyara savrulsunlar diye mi?” (s.132)... Benim yazgımı sürdürecekleri az çok belliydi. Kim bilir kaç sultana kul olacaklardı üç-beş yll sonra? Şimdiden yüreklerini ürkütse miydim? Dağ başlarında sürü otlatsalar böylesi hayattan iyi miydi?"(s. 134).

Merâgi Herat'ta evinde otururken dışarıdan yanık sesiyle Türkçe ilahi okuyan bir ses gelir (s.132). İlahi okuyan, gözlerine mil çekilmiş yaşlı bir adamdır. Yaşlı adamı içeri çağırırlar. O, Anadolu'dan geldiğini söyler, Timur'un, Anadolu'da Engürü yaylağında Yıldırım Beyazıt'a yaptıklarını anlatır. Yaşlı adam ilim erbabından olduğu için Timur'un askerleri onu öldürmemiş, gözlerine mil çekmiştir. Merâgi, yaşlı adamı dinledikçe Timur hanedanına hizmet ettiği için kendine çok kızar.

"Duyduğum her ne varsa, o kadar suç ortağıydım sanki... Hiç görmediğim Engürü Yaylağında Osmanlı padişahını bozguna uğratıp esir alan Moğol hakanı bendim... Şehzade Ertuğrul'un canına kıyan da... Halkı diri diri hendeklere gömen de... Dervişin gözlerine mil çektiren de... Ne bağışlanmaz günahlar işlemiştim ben? Timuroğullarının kapısında hizmet ettiğime göre... Boyumca kana bulanmıştım ben... Bestelerim de... Çalgılarım da... Yazmak istediğim kitap da... Yazacaklarım da... Başımdan saçılan altınlar da... Armağan edilen konaklar, bağlar, bahçeler de... Hünerimi öven fermanlar da" (s.135).

Merâgi, Timuroğlu Şahruh sultan olunca umutlanır, mutlu olur. Şahruh, Timur'un oğulları arasında paylaştırdığı toprakları birleştirir ve büyük bir devlet kurar. 20 yaşından itibaren halkının ona duyduğu güven artarak devam eder. Horasan-Herat bölgesine vali olduğundan, sonra sultanlık tacını giydiğinden 
Living in a Palace Slavery or Happiness? The Novel Named Gecenin Yalnzzhğında Abdülkadir Merâgi’s Relationship with The Government Relations and Musical Work / N. Özmen (p. 59-73)

beri uzun sürmeyen öfkesini şiir yazıp saz çalarak yatıştırır. Moğol saraylarında Şahruh’a benzer başka biri yoktur. Şahruh'un durumu Merâgi'yi çok mutlu eder (s.148). Şahruh'la Merâgi Herat'ta birçok kişinin ölümüne sebep olan veba hastalığı üzerine konuşurlarken Şahruh: "Çok kan döktük biz İbni Gaybî... Sülalemizi boğacak kadar... Yıldırım Beyazıt’ı esir aldığımız, ordusunu bozguna uğrattığımız düzlükte yükselen çığlıklar kulağımdan hiç gitmedi otuz üç ylldır" (s.15o) diyerek vebanın kendilerine Tanrı'nın bir cezası olduğunu, gönlünün asıl dileğinin artık dünyayı kılıçla değil sanatla fethetmek olduğunu belki böylece akıttıkları kanların yıkanacağını söyler (s.150).

Merâgi'nin Osmanlı ülkesi ve sultanına dair düşünceleri de vardır. O, Makasid’ül Elhan adlı eserini Şahruh'a sunar. Sonradan eksiklikler görerek bu eseri baştanbaşa yeniler. Osmanlı Sultanı II. Murat’a sunu yazısı ile mühürler. Ama Merâgi’ye, bu eseri Osmanlı Sultanına ne götürmek ne de göndermek kismet olur (s.153).

\section{B. Abdülkadir Meragi'nin Musiki Çalışmaları}

\section{1. İlhamı Nereden?}

Gecenin Yalnızh̆̆ında adlı romanda genelde Merâgi'nin saraydaki korkuları, endişeleri ve yalnızlı̆̆ı anlatılır. Endişelerinden uzaklaştığı bazı hâllerde veya kendiliğinden coştuğu zamanlarda müzik çalışması yapar. Romanda onun bestelerini nasıl yaptığı, ilhamı nereden aldığı bazı bölümlerde anlatılır. Merâgi daha ziyade tabiatı taklit eder. Musiki bilgini Urmiyeli Safiyüddin Abdülmümin’in Kitabُül Edvar'ını okurken hayale dalar. Şunları düşünür:

"Okuyamıyordum ne yapsam. Gözlerim kamaşıyordu. Çiçeklerin, kuru otların içinde gizlenmiş öten çekirgeler, hiç duymadığım ezgiler sunmaktaydı kulağıma. Ama ne devri belliydi, ne makamı. Uzzal mıydı gittikçe Hicaz’a dönüşen? Derken, hızla değişip Hüseyni oluveriyordu. Sonra Isfahan... Onda da karar kılmıyordu. Böyle giderse makam geçkisi sonsuz bir beste çıkacaktı ortaya... Sıcaktan bunalıp saçak altlarına, ağaç kovuklarına çekilmiş kuşlar suskundu yalnız. İyi ki onlar suskundu... Hepsiyle nasıl baş edecektim yoksa" (s. 10-11).

Bestelerini hayatı gözlemleyerek onlara dikkat kesilerek yapışını şöyle açıklar:

“Tan vaktine yakın uykuya yenik düşüp de gülün açıldığı anı hiçbir sabah göremeyen bülbülün seherde ağlayışını duymalıydı. Sofi çayın derinden derine çağlayışını... Kavrulmuş yapraklar arasında gölge arayan susuz kuşların iniltisini... Cimri bezirgandan alacağı 3-5 dirhem uğruna her gün hançeresini paralayan yoksul çığırtkanların akşama doğru kısılan sesleriyle müşteri çağırışını... O zavallılar sayesinde mallarını yorulmadan satabilen zengin tacirlerin halı döşeli sedirler, kadife perdelerle süslü serin dükkânlarında, gümüş zarflı billur bardaklarla ağızlarını şapırdata şapırdata soğuk şerbet içişini... İğrenç aksırmalarla enfiye çekişini... Bir sabah alacasında Hint kumaşı, Çin fağfuru yüklenmiş katar katar kervanların baharat kokuları saçarak Meraga'ya girişini... Yorgun develerin homurtuyla yere çöküşünü... Avlularda birbirine muştu veren kadın gülüşlerini... Bilezikli kolların şıngırtısını... Sokaklardaki oyun çocuklarını... Hışırdayan kavakları... Uğuldayan çamları... Çeşmeleri, sebilleri, şadırvanları... Kuyu çıkrıklarını... Bostan dolaplarını... Yel değirmenlerini... Nal şakırtılarını... Müezzinleri... Kilise çanlarını... Kıptî şarkılarını... Çerçileri. Başmakçıları... Dokumacıları... Bakırcıları... Kuyumcuları... Aynacıları... Camcıları... Oymacıları... Şehri gün boyunca dolduran bunca tını kulaklarımdan süzülüp akarken musiki yaratmakta iş miydi artık? 'Doğru doğru...' Haram sayılırdı uykuda geçen. 'Doğru, doğru...' Geceyi bile kısaltmak gerekirdi. Yatsı 
namazından sonra hemen yatağa girmek cahillere yakışırdı ancak. Muhabbeti derin dolunayla yıldızlarla sabaha dek yüz yüze söyleşmek; karanlığın sırlarını çözmek dururken, üç-beş saat uyku neyine yetmezdi Ademoğlu'nun? Sonra iklimden iklime yolculuk başlamalıydı. Meraga'dan uçup gitmeliydim Hüma’nın süslü kanadında. Maşrıktan Mağrip’e... Mağripten yine Maşrık’a... (s. 12-13).

Abdülkadir Merâgi bazen gökyüzündeki bulutların hareketini izleyerek beste yapar (s.16). Bunları ceylan derisi ile kaplı defterine gümüşlü divit takımı ile yazar. Bazen kendisine ilham olan nağmeleri kaydetmek için acele ile yerinden kalkar. Annesinin uykuyu çok fazla sevdiğini hatta gündüzleri bile uyuduğunu ifade ettikten sonra şöyle der: "Ne yapabilirdi başka? Çocukluğumdan beri baba oğul şiirle, musikiyle, yazıyla, zamanı insafsızca eritirken onu bir köşede unuturduk.” (s. 20).

Gıyasettin Mirza ondan daha önce hiç kullanılmamış bir usûl bulmasını ister. Merâgi Semerkan’tan ayrılan bir kervandaki develerin irili ufaklı çanlarından çıan nağmelerden bir şeyler çıkarmaya çalışır (s.114). Bu örnekte de görüldüğü gibi o bestelerini hep hayatın içindeki sesleri kullanarak yapar.

\section{Kıskananı Var mı?}

Merâgi, sarayda başarılı besteler yapıp güzel şiirler okudukça daha çok düşman kazandığına inanır. Sultan Üveys ve oğullarının bulunduğu bir mecliste başka musiki üstatlarının da bulunduğu bir sırada Sultan Üveys Merâgi'ye bir şeyler çalmasını işaret eder. Merâgi, gönülleri çiğnediğini ama buyruğa karşı gelemeyeceğini bilerek udunu eline alır ve çalar. Hanende ve sazendelerin kendini kıskandığını düşünür: "Belki sonumu hazırlayacak şey onların kıskançlıkları olacak” (s.46) diye düşünür.

\section{Anlattığını Yaşıyor mu?}

Merâgi'nin, şarkılarında dile getirdiği kadınlar ve eğlenceden uzak bir hayatı vardır (s. 50). Sarayda kendi iradesi ile eşini bile seçemeyeceğini düşünür: "Bir gün kendisine kılıç zoruyla bir nikâh" yapılacağının farkındadır (s.51). Kendi kendine: "Utanma söyle bir bakıma soytarı değil misin? Aşkın nice bir ateş olduğunu bilmeden sevda besteleri yapan koca bir aymaz" (s. 51) der. Bestelerini okuyup Sultanın eteğini öptükten sonra, bestelerinde söylediği şeyleri yaşamadığı için kendini bir yalancı olarak görür (s. 52).

Bir gün Sultan Hüseyin'e evc kâr okur. Onun zevkle dinlediğini görür. Şarkı bitince Sultanın eteğini öper. Şarkı da goncalardan güllerden bahsedip onların güzelliğini anlatır. Merâgi şarkısında dile getirdiği güzelliklere dair şöyle düşünür:

"Yalan! Ne gonca görmüşlüğüm var ne de gül... Yaprağına bile razıyım... Benden başka yirmi iki yaşında yalnız bir adam yok bu saltanat otağında. Benim yüreğim de yerinden oynamak, yolunu şaşırmak istiyor artık. Başkalarının adıma seçtiği bir kızı odamda buluvermek değil” (s. 52).

\section{Kendine Güveni Tam mı?}

Abdülkadir Merâgi kendi müzik kabiliyetine çok güvenir. Çünkü hüneri dillere destandır. Celayir Sultanı Hüseyin'le beraber devrin en büyük musiki üstatlarının (Hâce Şeyhü’l-Kucac, Emir Şemseddin Zekeriya, Ömer Şah, Mevlana Celaleddin Fazlullah) bulunduğu toplantıda Ramazan ayının her gününe bir tane olmak üzere, değişik makamlardan nevbet-i mürettep hazırlayacağını söyler (s.64). Meclisteki bütün müzisyenler hayretle Merâgi’ye bakar. Çünkü bu, nevbet-i mürettep beste türlerinin en zorudur. İçinde Arapça, Farsça beyitler, rubailer yer alan dört bölümlük bir silsile yaratmaktır. Raziyüddin Rıdvanşah 
Living in a Palace Slavery or Happiness? The Novel Named Gecenin Yalnzzlğında Abdülkadir Merâgi’s Relationship with The Government Relations and Musical Work / N. Özmen (p. 59-73)

Merâgi’nin sözünü imkânsız ölçüsünde görür (s. 64). Meclisteki diğer müzisyenler gibi Rıdvanşah da hayretle Merâgi'ye bakar. Şöyle der:

"Meragalı Abdülkadir dostumuzun hünerine saygımız sonsuzdur... Lakin bu iş başkadır... Hafife alınacak bir beste türü değildir nevbet-i mürettep (s.65). Meragalı Hafız Abdülkadir otuz nevbet-i mürettebi otuz Ramazan gecesinde dinletsin bizlere, huzurunuzda yeminim olsun ki, yüz bin altın dinar kendisine armağanım olacaktır." (s. 66).

Merâgi ise şöyle düşünür:

“Alçakgönüllülük uğruna o denli de baş eğmemeliydi hünerli kişi. Ünü Meraga’yı aşmış Abdülkadir İbni Gaybî idim ben. Eşi bulunmaz bir hafizın oğluydum. Tanrının bana armağan ettiği yeteneği çabalarımla geliştirip sultanlara beğendirmiştim kendimi” (s. 65).

Bir kayık gezintisi sırasında Ahmet Bahadır Han Abdülkadir Merâgi'den otuz kürekçiyi gösterip Cüneydi Bağdadi'den okuduğu beyitleri nağmelerle süslemesini ister. Abdülkadir Merâgi, Devr-i Şâhi dediği otuz vuruşlu usulde bir besteyi karaya ayak basmadan Sultana sunar (s. 124). Bunlar Merâgi’nin kendine güveninin tam olduğunu gösterir.

\section{Mutlu Zamanı Var mı?}

Ahmet Bahadır Han, Abdülkadir Merragi'den mâhûr kârı çalmasını ister. Merâgi udu ile çalar, söyler. Sultan Ahmet Bahadır mutlu olur. Merâgi de bu mutluluğa eşlik eder (s. 72).

Semerkant'ta eşi İkbal'le beraber konağında mutlu iken bir anda camdan içeriye rüzgâr eser. O anda Merâgi'nin bütün duyguları rast makamında saza dökülür. Muhammes usulünde nakış beste hemen hazır olur (s. 111).

Semerkant'ı gezer, evine gelir. Hamile olan eşi İkbal (Necm-i Hindî) oğlu Nureddin’i sever. Evde bir sükûnet ve huzur vardır. Merâgi coşar, rast makamında hafif usulde bir kârçe ile gönül yolculuğuna başlar (s. 129).

Merâgi, Herat'ta sarayın mektebinde bir gün kimlerin okuyacağını bilmeden musiki üzerine bir şeyler yazar (s.131). Ne yazdığına dair bir şey söylemez.

Merâgi, ders verdiği Baysungur Mektebinde iken bir sessizlik vardır, her şey durağandır. Öğrencisi Yusuf'a durgunluğun sebebini sorar. Yusuf: "Herat’a düşmüş ateş... Salgın gelmiş Horasan diyarında... Veba kol gezermiş Sultan diyarında" (s.142) der. Her yere hâkim bezginliği ben dağıtmalıyım diye düşünerek öğrencisi Hüsrev'den udunu ister. Hanendelere seslenir: "Silkinin yoldaşlar. Şimdi size dinleteceğim semai, daha önce işittiklerinizden biri değildir... Yaman kulak veresiniz” (s.143) der.

Abdülkadir Merâgi'nin babası Gıyasettin Gaybî kendini çalışmalarına verdiği için çocuklarına çok az vakit ayırmıştır. Merâgi de tıpkı babası gibi çocuklarına fazla vakit ayıramamıştır. Artık hastalanmış ve dışarı çıkmaz hâldedir. Oğlu Nurettin, Merâgi’ye: "artık kendisini çalgıları ve kitapları ile dolu odasına saklamadığını" yani çocukları ile daha fazla vakit geçirdiğini (s.152) söyler. Merâgi, yıllar önce kendisinin de babasına aynı şeyi söylediğini hatırlar (s.151). Babası Glyasettin Gaybî̉in annesine yaptığını Merâgi de eşi İkbal'e yapmıştır: "Ne garip çocukluğumda annemin tek başına 
yaşıyormuşçasına sürdürdüğü silik hayat yüzünden babamı için için suçlayan ben, kendi karıma aynı insafsızlığı yapmıştım.” (s.152) der.

\section{Sonuç}

Herhangi bir sanatkârın, yöneticinin himayesinde sarayda olması çok önemlidir. Bu, bazen, o sanatkârın büyüklüğüne bazen de padişah tarafından korunduğuna işarettir. Bu sebeple sanatkârların çoğu sarayda olmak için âdeta can atar. Bazıları bu mutluluğa ermek için uğraşır, arzusu gerçekleşmeyince hayal kırıklığına uğrar. Gecenin Yalnızlığında adlı romanda üstün yeteneklere sahip kurgu bir kahraman olan Abdülkadir Merâgi saraya, saray hizmetine girmek için hiçbir çaba sarf etmez, etmediği gibi sultan tarafından saraya davet edilmiş olmasını bile hayra yormaz. Saraya gidecek, orada bulunacak olmak onu rahatsız eder. Buna rağmen mecbur kaldığı için sultanın davetini kabul eder, saraya gider. Ancak orada yiyip-içip, mutlu-mesut günler geçirmek yerine devamlı bir ölüm endişesi ile yaşar. Bulunduğu saraylarda taht el değiştirdikçe ne zaman kim tarafından hayatına son verileceğini düşünür. Merâgi taht sahiplerini acımasız davranışları sebebiyle hep eleştirir ve saraydan kaçıp kurtulmanın yollarını arar. Kendince bunda haklıdır. Çünkü sultanların, yani idarecilerin ne kadar gaddar insanlar olduğuna, olabileceğine hep şahit olur. O, iradesine, hürriyetine ve rahat hareket etmesine engel olan saraya, dolayısıyla yöneticilere çok kızgındır. Kendisini sarayda bir esir gibi görür; çünkü hiçbir zaman iradesi ile hareket edemez. Merâgi'nin tek endişesi emniyette, hayatta olabilmektir. Merâgi'nin bu endişeleri müzik çalışmaları yapmasına, müzik üzerine düşünmesine engel olur. Merâgi’nin kendi müzik yeteneğine güveni sonsuzdur. Ancak müziğe dair düşünmeye çok fazla vakit ayıramaz. Romanın çok az bir kısmında onun müziğe dair fikirleri ve çalışmalarına yer verilir. Bu anlatıcının bir tercihidir. Çünkü normal şartlarda Merâgi'nin hayatı anlatılan bir romanda onun müzikle ilgili görüşleri, müziğe dair yorumları, bestelerinin anlatılması beklenirken anlatıcı, okuyucuyu şaşırtarak, esas anlamda, Merâgi'nin saraydaki mutsuzluğunu anlatır.

\section{Kaynakça}

Akengin, Ç.(2014). Sanat ideoloji politika ililişkileri. Ulakbilge, 2, (4), s. 140-350.

Çağan, K.(2004, Haziran, Temmuz, Ağustos). Sanat ve edebiyatın toplumsal perspektifi-siyasal ilişkilerine dair genel bir çözümleme. Hece dergisi, (90/91/92), s.73-83.

Çavuşoğlu, M.(1986, Temmuz, Ağustos, Eylül). Kaside. Türk Dili Türk Şiiri Özel Sayısı II Divan Şïiri, (415-416-417), s.21-22.

Çolak, S., Hilooğlu, C.(2010, Bahar). Osmanlı iktidar anlayışı çerçevesinde şiir. Bilig, (53), s. 89-102

Findıklı, S.(2002). Gecenin yalnızlığında, İstanbul: Remzi.

İnalckk, H.(2013). Şair ve patron patrimonyal devlet ve sanat üzerinde sosyolojik bir inceleme. İstanbul: Doğubatı.

Kolukırık, K.(2012). Abdülkâdir Merâgî ve Şurhü’l Edvar’’. Ankara: Atatürk Kültür Merkezi.

Özcan, N.(1998). Abdülkadir-i Merâgi. İslam Ansiklopedisi, 1, s.242-244. İstanbul: Türkiye Diyanet Vakfi.

Sağlık, Ş. (2004, Haziran, Temmuz, Ağustos). Edebiyatta bağlanma sorunu. Hece dergisi, (90/91/92), S.7-24.

Sazyek, H. (2004, 1). Romanda temel anlatım yöntemleri. Folklor-Edebiyat, s.103-118.

Uslu, R.(2017), Ünlü müzisyen Abdülkadir Meragi hakkında yeni bulgular. Erişim tarihi: 12.12.2017. http://dergipark.gov.tr/download/article-file/115282. 